\title{
Smart Eco Home: Towards Sustainable Community Within Relevant Strategic Integrated Intelligence of Architecture.
}

\author{
Mohamed Momen Afifi - Ahmed Adel Ismail \\ Architectural Department, Faculty of Engineering, Cairo University, Egypt
}

\begin{abstract}
While various countries all over the world suffer from a real energy lack, Energy becomes essential for economic evolution in any country for two main causes; first that its mandatory for domestic development, and it's a rich source of foreign currencies.

To avoid energy scarcity in Egypt; the community has to change its habits in different approaches and aspects to overcome any future lack in energy and at the same time to offer a sustainable community. Nowadays environmental technologies become an important discipline to take in consideration, as the sustainable smart approach will be a significant arena for economic competitions between building (especially Homes), which of them is more environmentally friend and fulfill human intelligent needs.

The main aim of this research is to consolidate Smart approach with ecological Discipline aiming to enhance ecological sustainability through integrated intelligent of architecture, the research gathered information about architecture chronological approaches through a logical review. Further, the research educes from this approaches an elaborated criterion to follow, and a real range for designers to apply in smart sustainable homes

This productive scientific intellectual offers specific procedures for innovating and designing a new compatibility viable architecture. this architecture countenance merging between two major poles, which are; building smartness and environmental control,
\end{abstract}


Turning residential buildings to Smart Ecological (SE) Home through; the application of intelligent and /or knowledge to automate the operation of building systems, the fulfillment of the ecological potentials concerning the environmental issue, preserving the natural environment, and minimize the economics used by home before and after construction. The study closes with the synthesis of main preliminary guide lines of the SE concept. Not only through hypothetical stage based on elaborated scientific search but also via practical investigation based on further analysis of the two major branches (smart-ecology). The purpose of the study is to create a new approach that integrates smart and ecological features with each other creating an elaborated approach that fulfill occupants needs, and at the same time provide comfort for occupants inside the homes. Also it offers energy conservation and a natural atmosphere desired for building consumers without harming the contiguous environment.

\section{Key Words}

Sustainable Homes, environmental control, vernacular approach, Smart building. intelligent approach, passive Design, building automation system, responsive controllers, energy management. renewable energy.

\section{Introduction}

Building industry and construction productiveness has a massive impact on environment as the environment is a present from our GOD that we have to save form any destructive issues. Designers has to put in consideration the pivotal challenge about environmental issues to maximize its existence and decrease harmful impacts on environment and building occupants. This research Explain the environmental concept and the categorization of environmental countenance, and the birth of the intelligent approach idea. And Clarify Smart building concept; identifying its significance, birth, development, progress, characteristics, principles and automations technologies. Furthermore, this study educed sustainable smart concept criteria form the Different approaches of architecture; identifying its meaning, assessment strategy, sustainability principles and technologies.

\section{Environmental Connotation:}

\subsection{Significance:}

A plentiful description for the environment; it is always used to refer to the natural; physical, and biological field, where different creature including human being lived in, mentioning social, political, dissipated, and rational field surround humans.

Architectural: It's the final physical image and the mirror for a specific place with all of its traditions and cultures in a specific time, furthermore architectural is a manmade witness to the direct and indirect relation between humans and natural environment (Badr Ahmed, Magda, march 2010). Actually environment is; the summation of all human and other living organism and all its contiguous, embedding natural forces(god creation) (www.businessdictionary.com). 


\subsection{Environmental Design Definition:}

\subsubsection{Definition:}

- Its relation to design and natural environment; it's an extraordinary performance property that cogitates and reduces its impact on the environment and human health. green building is designed to use less energy and water and to decrease the life-cycle ecological impacts of the materials casted or used. This is accomplished through, smart design, neat material selection, operation management, construction plan, maintenance strategy, and possible recycling methodology (Yudelson Jerry, 2008).

- Its relation to human being and economics; It's a part of design development process of the constructed environment to assign occupants needs and comfort conditions to human being with low operational expenses (Badr Ahmed, Magda, march 2010).

\subsubsection{Environmental Design Green principles:}

- Indoor Environment: creating a natural atmosphere in the indoor environment through selecting natural materials, systems, and passive technologies that doesn't affect the inside environment and doesn't emit toxic gasses inside the building.

- Energy conservation: reducing energy use by using passive Cooling strategy, passive heating tactic, and integrating natural lighting systems and at the same time using energy saving products to conserve and maintain energy.

- Natural ecological material: Selecting material according to its non-toxic characteristics and using material that is found in site to decrease overall carbon emission and at the same time decreases material cost(www.arch.hku.hk).

- Form: Designing the building form and plan related to the site and aligned with the surrounded area, the region and the climate, whereas taking in consideration the sustainable aspect inside the site. Building form should be homogeneous to the surrounding nature and to be harmonious to the residents.

- Design: Designers should achieve; efficient, effective, long lasting and elegant form which make use of every single line without ignoring building function and offers flexibility in design and circulation.

In another word green building rebellion is part of a paradigm shift toward sustainability (Yudelson Jerry, 2008).

\section{A Historical Review for Environmental and Intelligent Approaches in Architecture}

At the end of the 18th century 'unsustainable' architecture began, with the industrial revolution, as more new technologies were integrated into the fabric of buildings. Technologies were embedded in Buildings with different purposes, residential, industrial, and institutional. The subsequent history of this kind of architecture correlates quite precisely with the historical increase in global 
consumption of fossil fuels. (www.architecture.com). After the industrial revolution period, sustainability arises with its new agenda. Most architects design buildings that employed the properties of material and form to make appropriate adaptations to the relationships between their uses and the surrounding climates. The evidence of the many historic buildings that survive to the present day significantly complements all of this 'sustainable theory'. Actually all of these buildings are sustainable. Indeed, we can say that the history of sustainable architecture is the history of architecture since its modern origins. But that short history should be underpinned by awareness of the longer history. There are many lessons for new design that may be learned from the 'sustainable' buildings that pre-date the industrial revolution. Recent scholarship in environmental history is making these more available. (www.architecture.com/SustainabilityHub).

And hereby the historical development for the architecture meanings and aspects;

\subsubsection{Vernacular Approach:}

To identify vernacular architecture a lot of maturity levels of arguments has been discussed about this term. Obviously, Vernacular approach is a word used to categorize construction method that used locally, at which available resources and local traditions is the main pillar in specify vernacular architecture. Vernacular approach is sometimes referred to in practice as local architecture, as it addresses local needs and allied with occupant's traditions and circumstance. Furthermore, it reflects environmental and cultural and historical context in which this architecture exists (as shown in below figure).As vernacular architecture in Egypt will definitely differ from vernacular architecture in Mali, Despite the great variations in building forms and materials, each building subjected to the same law of physics(Oliver, Paul, 2003).

Forms, materials, structure even drawings are made to meet resident's specific needs accommodating morals, economies and ways of life of the nations that produce them. Paul Oliver in his book Dwellings, identify vernacular architecture as : "the architecture of the people, and by the people, but not for the people.

In another word vernacular approach always fulfill human being demands. the Egyptian architect Hassan Fathy was selected to design the town of New Gourna near Luxor. Hassan fathy first impression was that he should live with the original people to understand their actual needs and studying their traditions; he integrated the traditional mud brick vaults and domes of the Nubian settlements in his designs as they also have an environmental impact.(Oliver, Paul, 2003). Different vernacular architecture examples shown in followed figures.

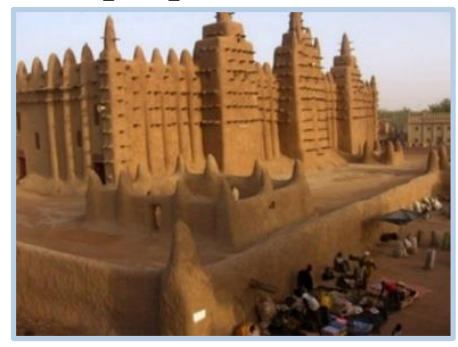

Figure1:Mali,Djenne Clay mosquevernaculararchitecture $(\mathrm{w}$ ww.fieldstudyoftheworld .com)

\footnotetext{
${ }^{1}$ Oliver paul was a researcher at the Oxford Institute for Sustainable Development (Department of Architecture, Oxford
} Brookes University), and from 1978-88 was Associate Head of the School of Architecture 


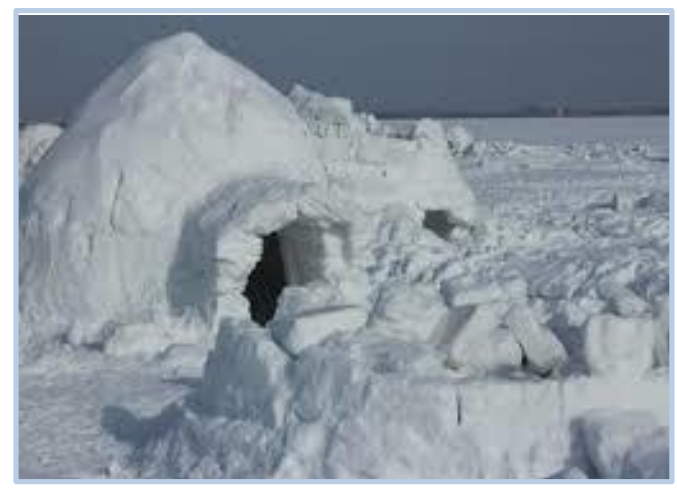

Figure 2: Anglo dwelling winter building. (www.pinterest.com)

\subsubsection{Traditional Approach:}

The challenge of defining traditional approach and its level of how much it doesn't harm surrounding environment, is detecting the fine line between legislations and traditions. actually traditional architecture composed by traditions and legislation. Architecture that ruled by building regulations and neighborhood suitability and eligibility. Variety of examples for traditional architecture such as; EL GHORY mosque, EL SULTAN HASSAN Mosque, the great ancient Egyptian temples ;(EL KARNAK temple, EDFO temple), EL SEHEMY house. This type of architecture appears to be aligned with the surrounded environs either on the climatic level or social one. Added dimension to traditional architecture is to conserve the land-dwelling with the natural environment aiming to fulfill human being with healthy life and brilliant atmosphere without ignoring financial, mental, physiological needs (Badr Ahmed, Magda, march 2010).

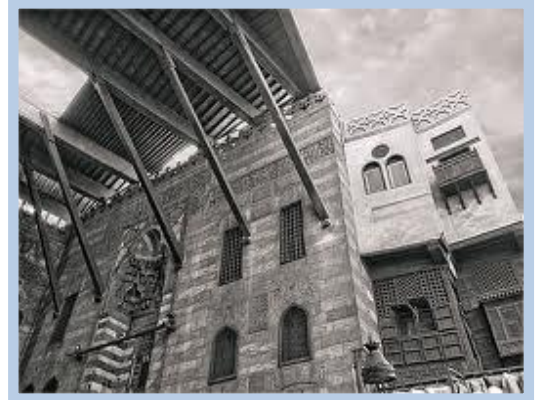

Figure 4: El Sultan El GHOREY mosque (www.archinet.org)

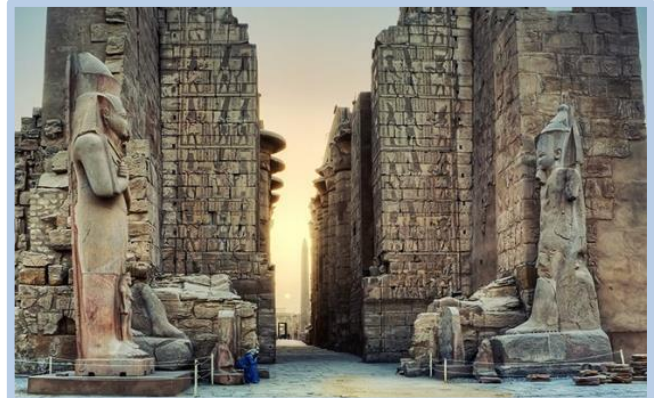

Figure 5 :Karnak Temple Luxor (www.gattours.com) 


\subsubsection{Ecological Approach:}

The ecological concept comes to life in the $19^{\text {th }}$ century through (Ernst Haeckel) $^{2}$ works. ecology definition; is the study of human being living places and any other thing surrounds it (Badr Ahmed, Magda, march 2010).

The lack of signifying the importance of environment in this period; is the main catalyst for designers to innovate this type of architecture. Ecological architecture is an approach that make full use of natural resources, satisfy inhabitant demands under healthy umbrella, and offers applicability, effectiveness to achieve harmony between human being and architectures. Only if in a balanced state, the ecological concept and the sustainable development can be achieved through the overall design principles. Consequently, ecological design principles determined in various components starting from the site, plan, design, function, materials selection, technical approach, operation and maintenance. all these aspects are eventually responsible on how much building is environmentally satisfactory and ecological adequate (Lan, Ma,2011).

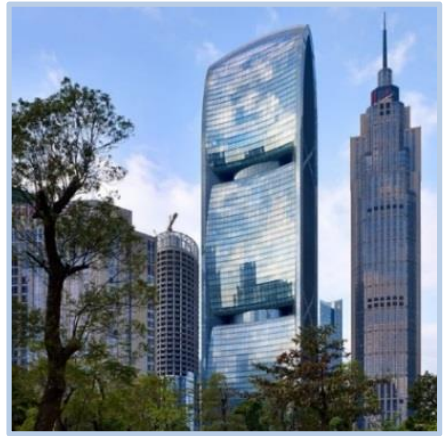

Figure 6: Nanyang

Technical University in

Singapore

(www.artefactinc.com)

Figure 7 : pearl river

(www.som.com)

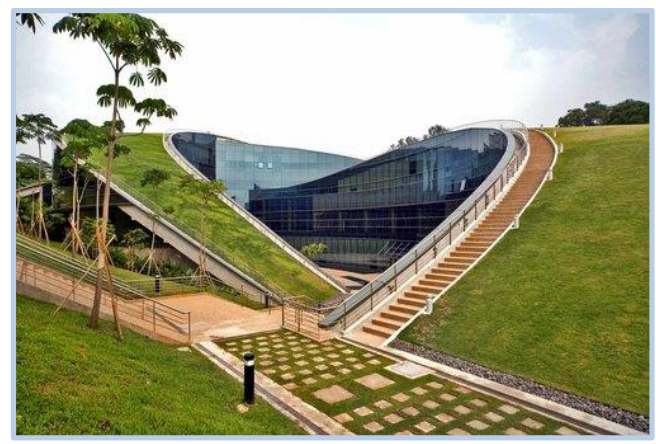

Zero energy building is a substitute phrase to ecological building as ecological architecture main purpose is to improve the utilization of energy and make use of natural sunlight, wind, rain, any other natural resources. Also to decrease waste of nonrenewable resources and advocates recycling concept and reuse of natural resources that produce energy like photovoltaic cells (Lan, Ma, 2011). One of the major idea that reformed environmental track in ecological aspect is the harmony between man and nature. Actually Ecological architecture developed from obscurity to clarity, from idealism to realism, with a very quick performance and development.

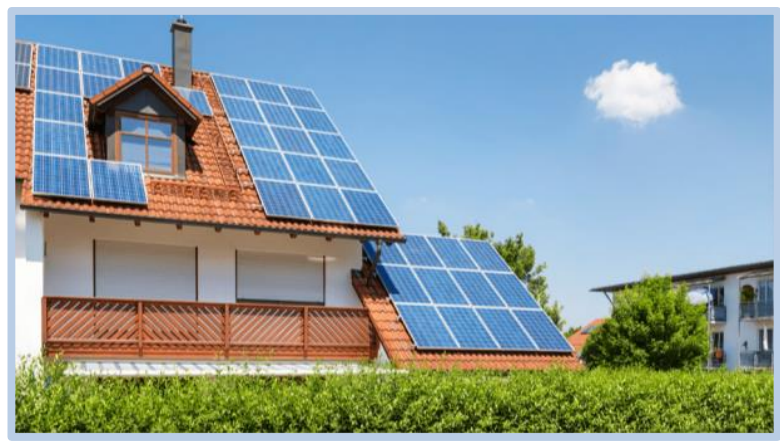

Figure 8 :solar energy roof-photovoltaic cell integration (www.roofkingnc.com)

\footnotetext{
${ }^{2}$ Ernst Heinrich Philipp August Haeckel (February 16, 1834 - August 9, 1919), was a German biologist, naturalist, philosopher, physician, professor and artist who discovered, described and named thousands of new species, mapped a genealogical tree relating all life forms, and coined many terms in biology, including anthropogony, ecology, phylum, phylogeny, and stem cell.
} 
Although ecological building is an inorganic artifact constructed for man use, there are considerable efforts made by the designers to convert building from usual conventional building to ecological building with a specific material that bring a real ecological benefit to environment; architects such as Shigeru Ban and Kengo Kuma have used ecological material as paper in constructing dome of Hannover building, Germany.

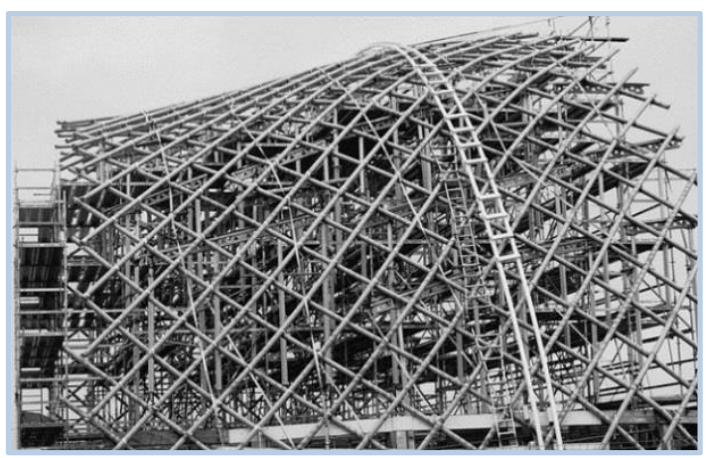

Figure 10:generating sustainable construction (Dome of Hannover)

(www.architecturalreview.com)

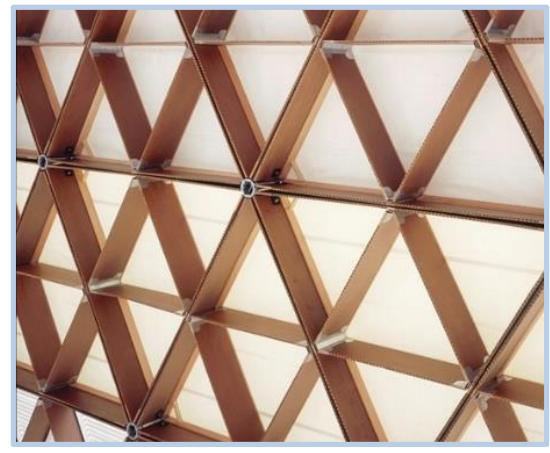

Figure 9 :The Japanese pavilion is the biggest paper structure ever built (www.architectural-review.com)

\subsubsection{Bio-climatic Approach:}

The use of various natural techniques and strategies in design tends to integrate building with the surrounding and that's how bioclimatic architecture attain. Bioclimatic architecture is the approach that; offers design fulfills people needs and offer comfort for tenants (thermal, iridescent and acoustic), is mindful to climatic conditions; utilizes strategies which incorporate the capacity and information of how to permit daylight, heat and prevailed wind through the dwelling envelope just when required, at appropriate occasions during the day and in proper months of the year; utilizes materials accessible in the area; and attempts to consolidate the building with the natural environment

Ancient Egyptian architect's assets bioclimatic and green approach without nowadays technologies they become proficient at those disciplines without today tactic; 3500 years ago they designed by specific and neat calculation opening that permit light (sun rays) to reach (Ramses II) mask just once per year, lighting it for a very few minutes.

When UNESCO was responsible about transferring this temple to save from Nile flood as a consequences of the high dam they faced a lot of problems reproducing the same effect achieved by ancient architects in spite of the modern computers and sophisticated measuring instruments (Gallo, Cettina, May-August 1996).

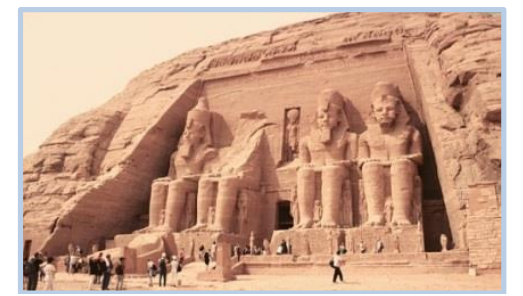

Figure 11 : The Great Temple of RamsesII (www.bluffton.edu)

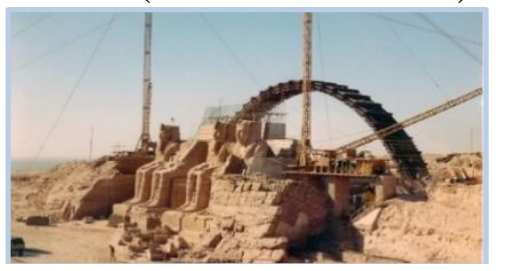

Figure 12:relocating Abo Simble Temple(www.mashable.com) 


\subsubsection{Bio-geometrical Approach:}

In the field of architecture spaces not only affected with anything inside it like the amount of air, sound conductance, isolation and heat. Nut also affected by forms and shapes made by the architects. Bio-Geometry is the science that studies the influence of angles and shapes and over all form on humans and on different energy fields. Furthermore, Bio-Geometry offers remedies to the architectural pollution humans suffering from (www.biogeometry.com).

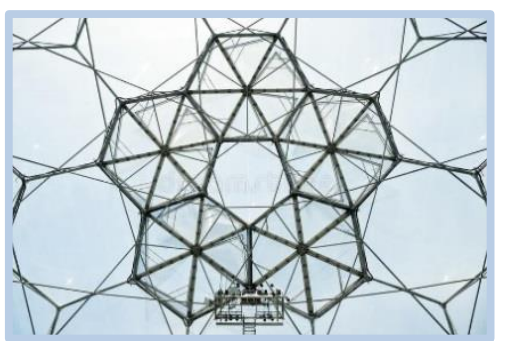

\subsubsection{Organic Approach:}

Organic architecture was firstly developed by Frank Lloyd Wright, Louis Sullivan and Claude Bragdon. organic approach is a way of thinking of design that consolidates among environment and human being this concordance is made through design. Organic approach isn't a style to apply yet a standard to pursue. principle that incorporates nature to building shapes which seems progressively naturalistic (Frank Lloyd Wright ,1954) Organic architecture arguably has better capabilities than traditional architecture as it uses nature design as one of its basis criteria in design.

In another word it design building in a matter to grow as environment grows (www.organicarchitect.com) A list of aspects about organic approach that designers should take in consideration list by David pearson ${ }^{3}$ :

- Be propelled essentially and be practical, sustainable, saving nature, and healthy, Unfurl, similar to a creature, from the seed inside

- Exist in the "eternal present" and "start over and over".

- Pursue streams and be adaptable, Fulfill social, physical, and profound needs.

- Develop out of the site and be exceptional (Pearson, David, 2001).

Figure 16 :Zaha Hadid Architect Project -Heydar Aliyev Center (www.cgarchitect.com)

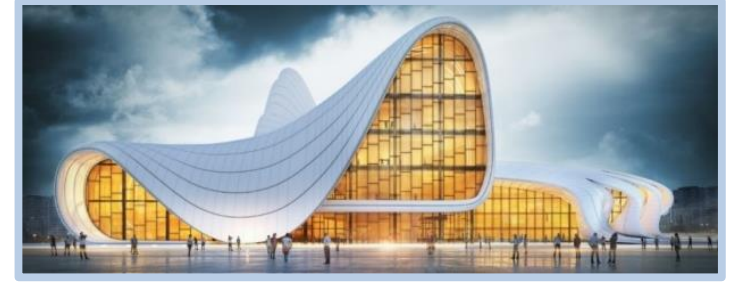

\footnotetext{
${ }^{3}$ David Pearson is a London-based architect who he is the founder of the Ecological Design Associates and a founder of Gaia International, an innovative group of eco-architects from twelve countries.
} 


\subsubsection{Solar Approach:}

The influence of light has always been essential to the designers. It establishes common tactics in different architecture approaches, both lighting designers and architects are tackling with natural sun rays as a source of solar energy and their real challenge is embedding these sunrays in design through passive and active technologies. Designers main target is to use natural day light deprived of glare and at the same time not to expose inner space to solar overheating (Porteus, Colin, June 2008), We are able to categorize solar energy into passive and active technology:

\section{- Active solar technologies:}

It is innovation changes over sun energy into another type of vitality. This type of energy can be utilized inside the dwelling as a type of warming or cooling. Dynamic sun powered heating or cooling framework is an innovation that drives mechanical methods or electrical apparatus to sort of dynamism and disturbed sun energy inside dwelling in an appropriate manner (www.cmhc-schl.gc.ca).

\section{- Passive solar technologies:}

Passive design standard is a collaborative production that collect, save and dispense solar energy in an another form. On a more concise level passive techniques convert energy to heat in winter and discard solar warmness in seasonal hot months. Windows, floor, facades, and walls are the features that help in omitting or absorbing heat inside the buildings.The main concern of passive solar design is that it focusses on natural climatic remedies. Acutely the real difference between passive and active solar techniques is that active techniques depend on mechanical and electrical devices, and on the contrary passive technologies rely on thermal insulation, glazing type, window size and placement, shading tactics, building forms and orientation (Doerr, Thomas ,2012).

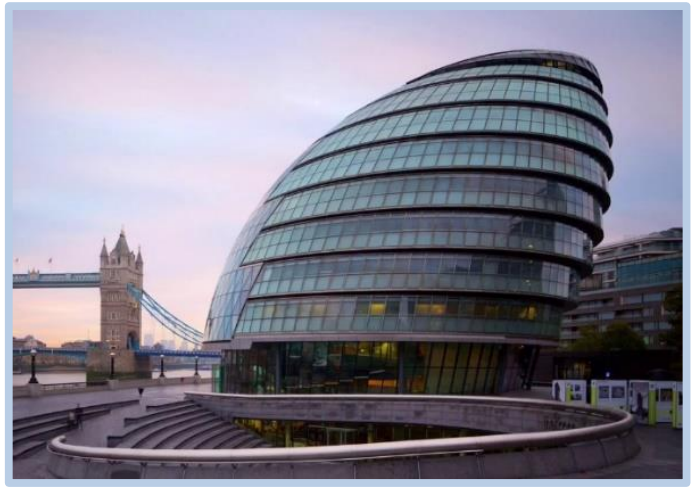

Figure 17: City Hall By Norman Foster active design (www.archidialouge.com)

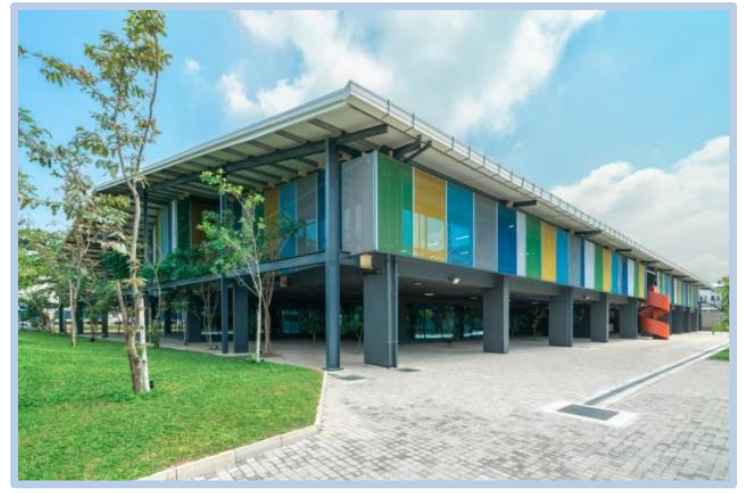

Figure 18: Passive House project in South Asia Sri Lanka www.constructionspecifier.com

\subsubsection{Sustainable Approach:}

Sustainable approach is the way to meet essential needs of human being, without infringement or invasion future generation's needs. The sustainable design is the 
crossing point between mechanical actuators, construction engineering and architectural significance. sustainable image achieved not only through forms, beauty shadow and light, but sustainable design should acquire human aspect, economic facet, and environmental features along building life cycle (Mohamed, Nura S.; Darus, Zuhairuse M. D., 2011).

The Rocky-mountain institute ${ }^{4}$ determined five elements of sustainable design:

- Speculation of planning and design, and primer choices (in design early stage) greatly affects the effectiveness of energy use in building.

- Practical sustainable design is a development theory more than being a development construction plan; Buildings built by this philosophy are not with certain shape or highlight.

- Cost of sustainable dwellings is almost equivalent to old traditional buildings moreover they are not diverse from them in simplicity.

- Decrease of energy use and improving individuals' wellbeing are standards of feasible sustainable approach.

There is also another component that should incorporated sustainable design:

- Maintaining Energy.

- The Architectural Features of dwellings.

- Examining the outer surface of the building and what degree it monitors and conserves energy.

- Utilization of electrical and mechanical frameworks proficiently.

- Making a reasonable healthy environment for building occupants.

For the sake of consistency sustainable design focuses on the significance of ecological effect on building design through site estimation. This requires an elaborated assessment to all activates related to building operation, whether this activates are execution equipment used in construction or used materials in architectural specifications. Moreover, this evaluation gets more detailed to the toxicity of used construction materials that make bad or negative effects on building residents, aiming to create a pollution - free natural healthy environs (Mohamed, Nura S.; Darus, Zuhairuse M. D., 2011).

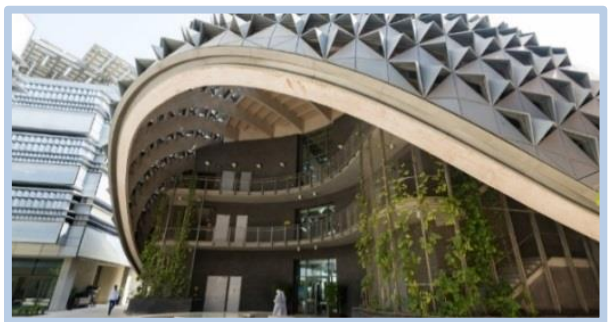

Figure 20: MASDAR CITY, A model of environmental city (www.aboutenergy.com)

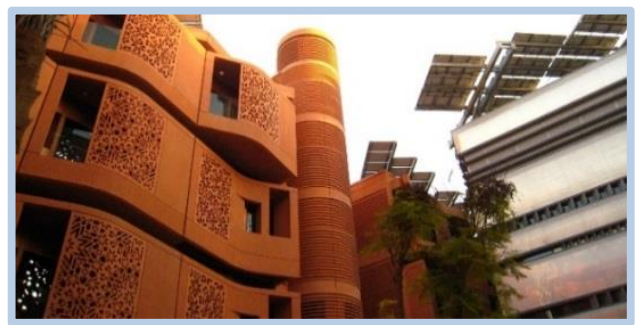

Figure 19:Masdar City, Abu Dhabi, United Arab Emirates (www.arup.com)

\footnotetext{
${ }^{4}$ Rocky Mountain Institute (RMI) is an organization in the United States dedicated to research, publication, consulting, and lecturing in the general field of sustainability, with a special focus on profitable innovations for energy and resource efficiency. RMI was established in 1982.
} 


\subsubsection{Smart Approach:}

Through Deep architectural perspective, primitive smart building is not sophisticated as new intelligent design. Those embryonic designs were intelligent cause of their forms, materials, and orientation. Despite the great value of those old aspects a new one relationship took place between inhabitants and technologies of built form. This intimate correlation designed to make users interrelate with building's numerous systems. These systems offer occupant a lot of facilities that make them to; adjust, modify, and adapting inner space and outer architectural features with the currently situation, whether this situation is functional or/and social, aiming to fulfill users with comfort atmosphere and a brilliant indoor quality (Walter M. Kroner, 1989).

Definition by (intelligent building institute in Washington dc):

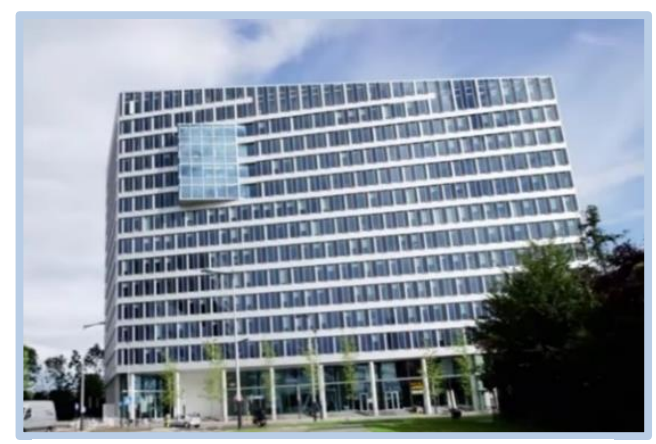

Figure 21 :the edge building in Amsterdam is one of the most smartness building in the world.

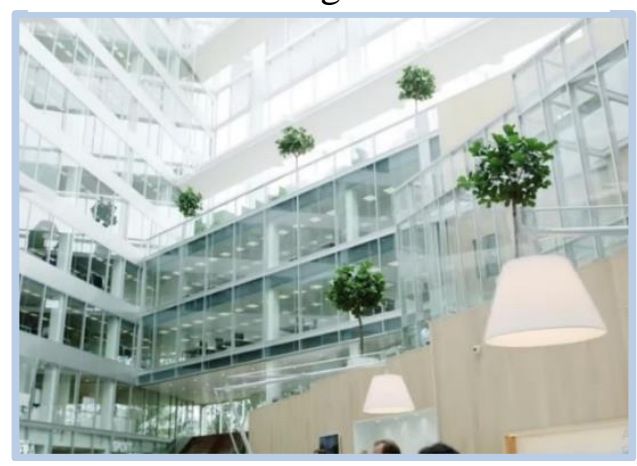

Figure 22: Edge smart building (interior). intelligent building is the building which incorporates different frameworks, (for example, lighting, HVAC, voice and information correspondences, and other structure capacities) to successfully manage resources in a planned mode to amplify; tenant performance, investment, cost-saving, and adaptability.

Different degrees of insight are given through intelligent controls and communication actuators. Common occupant services are; principally a voice and data media communications function which is shared among various independent users, is a component of intelligent buildings.

The National Research Council ${ }^{5}$, Washington, DCA state in another term that smart building is 'electronically enhanced building', Furthermore it add that smart building is a building that is fully equipped with controllers and systems and a real infrastructure to help the utilization of cutting edge correspondence, information handling, and control advances by its inhabitants and operating staff. Such a building is outfitted with the essential wires, links, conduits, control supply, warming, ventilating, cooling, illumination, sound insulation, and security frameworks to help the performance requirements of today's office environs. (Walter M. Korner,1989).

\footnotetext{
${ }^{5}$ The National Research Council (NRC) of the USA is the working arm of the United States National Academies, carrying out most of the studies done in their names, it was organized in 1916 in response to the increased need for scientific and technical services caused by World War I.
} 
The strongest association in intelligent building that if can perform through different aspects and features, smart building can be formed by using intelligent materials and structure cabling, which is connected to a multimedia communication system to transfer data (send or/ and receiving) between actuators and various management systems. As explained any smart system should acquire a specific framework that consist of management system to monitor and automate controllers and system to fulfill occupants needs (Andreas muller,2007). The basic criteria by which the building considered to be intelligent are:

- Info framework that gets data by means of info receiver.

- Preparing and information investigation and analysis

- Yield framework that responds to the contribution to type of a reaction.

- Time consideration that causes the reaction that occurs within the required time.

- Learning capability

- Brilliant intelligent materials

Intelligent building should comprise all of these features and systems (Andreas muller,2007).

Technical system for smart building is a mean to test objective controllers by deploying A lot of points as a nervous limp all over the building. This nervous hitches regulate and supervise dwelling purposes and routine. Alternatively, all of this is connected to building management system that control, learn and response to action and save desired reaction (Sayed abd el fatah, Eman, 2010).

As mentioned before any smart building should have building management system or building monitoring system and building automation system, with a specific principles and controllers which are:

-Occupancy regulator

-Responsive lighting technology

Ventilation controllers

Heating and cooling temperature controller
-Controllers

-Air handle unit

-Alarm and security

-Electricity generator

\subsubsection{Historical Progress from Vernacular to Smart Architecture}

The chronological progress from the vernacular architecture to smart architecture is the normal development not only according to the human being needs, but also according to the environmental aspects. Staring from the human needs in the traditional architecture passing by sustainable, solar, high technology, and green architecture and ends with the scientific integration between nature and technology; the smart technology that enhance human being life and manage it to the comfort zone. Smart discipline is an elaborated approach that deals with problem in a responsive way. This approach has the ability to deal, interact, and learn. Smart architecture has the learning ability; it learns how to deal with different circumstances according to inhabitant adjustments. Despite the great impact worldwide about aversion smart approach, this discipline proves that it can solve problems without harming nature (Ed van Hinte, etal, 2003). 


\section{Integration of Sustainable Smart Concept from Finding Principles Case and Verification:}

Stating this logical procedures of architecture various approach, investigate domain related issues concerning energy saving and consumption. Along this decade humans main concern is how to produce energy and main its presence for a long time, without ignoring its prices and the impact of its production and usage on natural environment (Ali Safdar, Kim Dohyeun.2013) The Study focus on household electricity as it's a very essential subject in the field of energy consumption as according to Egypt minister of energy residential section consumption is too high compared to industrial and other purposes. Actually this is because of the wide urban expansion as a result of country conditions (www.moee.gov.eg).

Figure 23 :Total

Sold Energy on

all Voltages

Classified according to uses $(\mathrm{GWh})$ (www.moee.gov . eg)

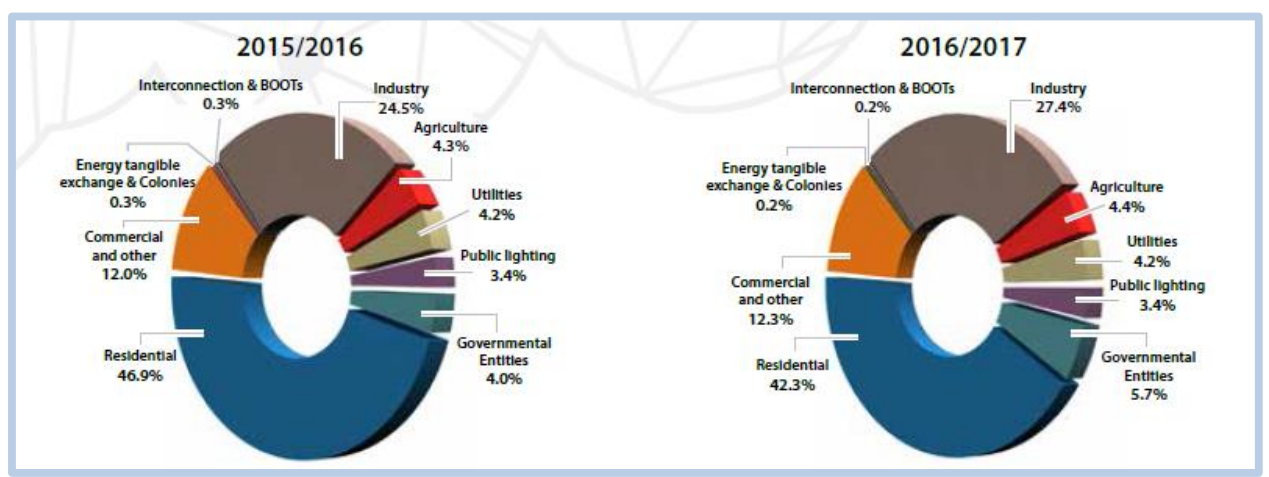

A robust of applications and techniques used in dissimilar architecture approaches that wishes to achieve habitant's comfort inside the dwellings. actually this active and passive techniques have a main propose which is; reaching energy efficiency inside homes, and achieving an accepted Indoor Air Quality (IAQ) (www.epa.gov/indoor-airquality). Keeping the indoor condition healthy and accomplishing an energy productive criteria in the dwellings should be possible done by following this strategies:

- Lessening cooling loads as cooling homes in hot areas is one of inhabitant's problems, and this by its turn it will diminish energy consumption.

- Decreasing thermal bridging by isolating building envelope.

- Giving a genuine approach to diminish the use of air conditioners

- Executing passive and low tech strategies to improve (IAQ) via; selecting regular and eco-accommodating materials, augmenting the utilization of natural ventilation, enhancing acoustics, and enhancing natural daylight usage.

- Upgrade and developed supportive maintenance plan with a low expense.

- Integrating new renewable energy system to fulfill building energy needs.

- Decreasing waste, embodied energy, and pollution. (Ali Safdar, Kim Dohyeun.2013).

Optimizing these wide guidelines, we need to get more deep in the principles and technologies to follow in design: 


\subsection{Passive Cooling \\ 4.1.1. Definition:}

Passive cooling strategies considered as the least expensive techniques which focus on the mean of cooling. Using active cooling tactics such as air conditioning hits energy consumption to the max. Alternatively, using passive cooling strategies is the most appropriate approach to nowadays trend. passive cooling technologies rely on natural techniques to remove heat from building and originate cooling from convection, radiation (without actuators), and evaporation. Actually, all passive cooling approaches bank on everyday deviations in temperature and humidity (Chris Reardon, et al.,2013)

\subsubsection{Sustainable Passive Design techniques used in smart homes:}

Inactive cooling energy frameworks are essentially significant in accomplishing effective design and performative assembled condition in the manmade environment. Reassuringly, there are numerous detached cooling energy frameworks at three spatial levels of Macro, Meso and Micro (Ayotunde Dawodua, Ali Cheshmehzangia ,2017). These three levels identify knowledge techniques and squeeze passive cooling strategy on micro level (dwellings) to specific points which are;

-Solar Shading

-Thermal Mass and Materials

-Solar Chimney

-Wind Catcher

-Building Envelop.

Figure 24: passive cooling energy system at three spatial levels

(Ayotunde Dawodua, Ali

Cheshmehzangia,2017)

\subsection{Passive heating:}

\subsubsection{Description and purpose:}

-Greening

-Insulation

-Air Vents

-Evaporative Cooling

\begin{tabular}{|l|l|l|}
\hline Macro level & Meso level & Micro level \\
\hline -Urban geometry \& pattern & -Urban Layout & -Solar Shading \\
\hline -Urban canyons & -Density & -Greening (shading) \\
-Urban cool islands & -Orientation & -Thermal mass and Materials \\
-Green infra structure & -Compactness & -Insulation \\
-Bio-climatic planning and & -Construction material & -Solar Chimney \\
design & -Green Infrastructure & -Air Vents Natural Ventilation- \\
& & wind catcher \\
& & -evaporative cooling \\
& -earth cooling \\
& -building envelope \\
\hline
\end{tabular}

Passive solar design refers to the use of the sun's energy for the heating and cooling of living spaces by exposure to the sun. When sunlight strikes a building, the building materials can reflect, transmit, or absorb the solar radiation. In addition, the heat produced by the sun causes air movement that can be predictable in designed spaces. These basic responses to solar heat lead to design elements, material choices and placements that can provide heating and cooling effects in a home. there are two types of passive heating through direct gain and indirect gainx(www.sustainability.williams.edu).

\subsubsection{Passive design protocols and techniques:}

\section{A.Orientation}

The goal of passive solar heating systems is to capture the sun's heat within the building's elements and to release that heat during periods when the sun is absent, while also maintaining a comfortable room temperature. The two primary elements of 
passive solar heating are south facing glass and thermal mass to absorb, store, and distribute heat (www.sustainability.williams.edu).It is generally agreed that a southern orientation is optimal for gaining heat in the winter and for controlling solar radiation in the summer (Mingfang T.,2002). Designers studied the relation between building orientation and shape. They found that the eastern orientation of the building surface was what most contributed to an increase in the heating energy demand (Florides GA, et al,2002).

\section{B. Trombe wall- direct solar gain}

Trombe wall common idea is to create a thermal mass through implementing a 618-inch-thick masonry wall usually colored with black painted, this wall is located immediately behind south facing glass of single or double layer, which is mounted about 1 inch or less in front of the wall's surface as in (figure29) (EvangelosBellos,et.al,2013).

\subsection{Natural ventilation 4.3.1. Definition:}

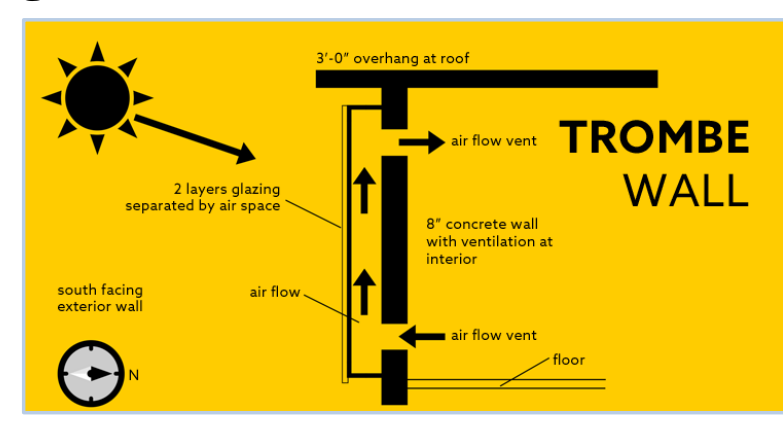

Figure 25: Trombe wall concept

(www.qpractice.com)

Natural ventilation is the process of supplying air to and removing air from an indoor space without using systems. There are two types of natural ventilation occurring in buildings wind: Wind driven ventilation; arises from the different pressures; Buoyancy-driven ventilation; occurs as a result of the directional (Linden, P. F., 1999).

\subsubsection{Techniques:}

Natural ventilation has become an increasingly attractive method for reducing energy use and cost and for providing acceptable indoor environmental quality and maintaining a healthy, comfortable, and productive indoor climate. natural ventilation can be used as an alternative to air-conditioning as it roughly saves $10 \%-30 \%$ of total energy consumption. Natural ventilation systems rely on pressure differences to move fresh air through buildings. Pressure differences can be caused by wind or the buoyancy effect created by temperature differences or differences in humidity (Walker, Andy,2019).

\section{A.Design and form}

Specific techniques and Design guidelines offered in a building regulated with a variety of recommendation to achieve natural ventilation strategy such as:

- Building location and orientation, form and dimensions

- Indoor partitions and layout, Window typologies, location, and shapes.

- Other aperture types (doors, chimneys) External elements (walls, screens).

Overtly, the amount of ventilation depends critically on the mature design of internal spaces, and opening size and placement in the building. 


\section{B. EAHE}

Earth-Air Heat Exchangers (EAHE) is a technique used to improve the thermal conditions inside built environments and enhance indoor air quality, EAHE works by pumping the air through buried ducts to use the soil as heat source or sink. turning possible to heat the air in the winter or cool it in the summer. By means of Constructed Design strategies (Trilok Singh Bisoniya,2013).

\section{Green walls and Vertical farming:}

Green systems (green roofs and green walls) are considered as sustainable strategies due to their great environmental advantages; from air purifying, façade insulation, and source of oxygen release 24/7. Green walls can also be classified in to two groups based on their construction characteristics as represented (Hossein Omrany, et al,2016).

- Green façades; are the plants that grow up vertically up wards or down wards the buildings through climbing or hanging along the walls (Manso M, CastroGomesJ,2015).

- Living walls; Living walls system(LWS) is an innovative solution in the field of cladding walls. Living walls are able to integrate green walls in high-rise buildings.

Providing the inner spaces with proper fresh air to enhance the indoor air quality happens through one or more from the above techniques started from the home Design and form, the smart distribution of horizontal and vertical pipes and air inlets and floor vents, Earth heat exchanger, wind catchers, and green farming and integrated green wall (Wong, et al.,2017).

\subsection{Water management}

Water management is the activity of planning, developing, distributing and optimum use of water resources under defined water polices and regulations. It includes: management of water treatment of drinking water, industrial water, sewage or wastewater, management of water resources, management of flood protection, management of irrigation, and management of the water table. Water management become one of the mandatory remedies to overcome water scarcity and the great loss in water levelall over the world (Walmsly, N., Pearce, G.,2010).

\subsubsection{Techniques and consumption saving strategies:}

\section{A.Grey Water management system:}

Grey water is becoming increasingly important. It is the most used type of water in the world, and the most wasted on a daily basis (Snigdhendubala Pradhan,2019). Decentralized treatment and recycling of greywater is preferred for two reasons: because of the simpler treatment systems required and the reduced public health risks 
associated with these systems, compared to combined wastewater treatment systems (Prathapar, S., et al.,2005). treated Grey water can be used; to wash clothes, water the garden, wash our vehicles or water a constructed wetland. (Snigdhendubala Pradhan,2019)

\section{B.Rain water harvesting system:}

Integration of rainwater harvesting and greywater reuse systems can result in significant water savings. Studies to evaluate the potential for potable water savings by using rainwater and greywater in houses and multi-story residential buildings have been conducted, showing water savings on the order of $36 \%$ in houses and $42 \%$ in multi-story residential buildings (Ghisi, E.; de Oliveira, S.M.2007).

\section{C.Sustainable Water Fixture:}

- Low pressure toilet flushing

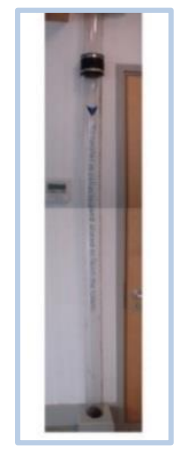

Figure 28: rain water recycling system.

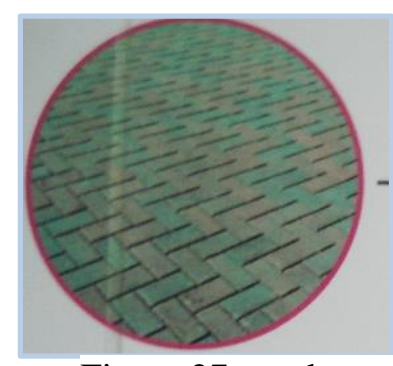

Figure 27: outdoor interlock collect rain water - Researcher_ BRE innovation park(England)

It was proposed the replacement of the high-pressure toilet flushing by low-pressure ones, (Santos, F. M.,et al,2017)which provides economy in the water volume per flushing as well as easy maintenance (Larissa Carolina Corraide da Silvaa,et al,2019).

- Water taps with aerators

Aerators connected to the outlet end of the tap significantly change water flow, contributing to save this natural resource. Therefore, water consumption decreases (Demanboro, A. C.,et al ,2015)

\subsubsection{Smart process and natural passive techniques:}

\section{A. Separation and treatment process:}

Various cost-effective treatment technologies like sand filters, and subsurface wetlands are used for greywater treatment as they require less energy and lower maintenance.

\section{- Sand filter:}

In low-tech greywater filters, the wastewater flows through a filter medium - sand or gravel. The main treatment process encompasses the retention of particles by the filter material and cleaning processes due to biological activity in the biofilm on the sand or gravel (Lukas Huhn,et al,2015).

\section{- Subsurface wetland}

As the name implies a subsurface flow constructed wetlands means the greywater flows below the media in the wetlands. Generally, there is generally a base layer of large stone, a layer of gravel, a filter fabric, a layer of sand, topped off by a layer of growing media filled with plants. This system can be used for irrigation, toilet flushing, or other non-potable uses (www.appropedia.org). 


\section{B. Mixing ratios}

the residential unit water waste mainly comes from kitchen, bath, and laundry. For bathrooms' grey water; collected at floor drain from shower and vanity sink then sent to grey water tank at ground level, while separating toilet urine waste is connected to a separated urine tank placed at ground floor level or outside the building, laundry drainage and kitchen

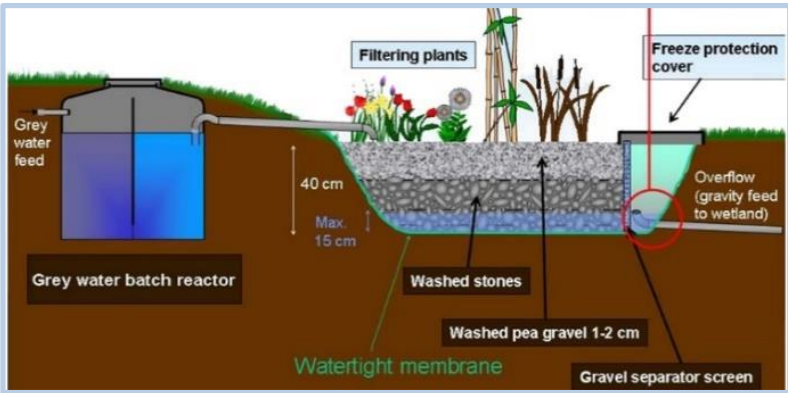

Figure 29: subsurface wetland filter

(www.eautarcie.org) sink is connected together to the same drainage pipe towards grey water tank. Grey water tank is used for filtering, settlements of solid, floating and separation of lighter solid, while urine tank used for storing separately to be send to the mixing tank to mix urine with a certain ratio with water comes out from grey tank. The mixing tank is used to mix the water from grey tank with the urine from urine tank with a ratio 1 urine unit:10 grey water units. This mixture used in plant irrigation as it works as a plant nourishment, it contains nutrients for the plants. designers should not use the mixing tanks to irrigate facade vegetation to avoid any odor to comes inside home.

\subsection{Energy production}

\subsubsection{Renewable Energy Systems and Technologies}

\section{A.Solar Energy System}

Solar energy is one of the cheapest and sustainable renewable energy that is used in homes. photovoltaic system is installed on the roof on-site or centrally off-site. For the intelligent houses, the System can be connected with the electricity grid or off-grid system (F.L. Luo, H. Ye,2013). For solar thermal, the solar hot water is very popular in house-holds in all over the world. Using the solar thermal for domestic hot water will reduce drastically the electricity consumption in case of the electric heaters and the gas consumption in case of hot water boilers (Fadi AlFaris, et al ,2017). All photovoltaic (PV) cells consist of two or more thin layers of semi-conducting material, most commonly silicon. Solar cells are not just for roofs anymore. A various shapes and design options are available now days for integrating photovoltaic in houses such as; Solar Façade, Solar Shingles, Solar Porch, Solar Skylight, Solar Shade modules (www.nef.org.uk).

\section{B. Wind energy system}

Merging windmills technology to compensate energy consumption close to energy generation and electricity production. there are two different ways to integrate wind turbine in building. Either through massive wind turbines that tower stories high, or to think small. In fact, small wind energy is becoming more and more common as a home renewable energy option. 


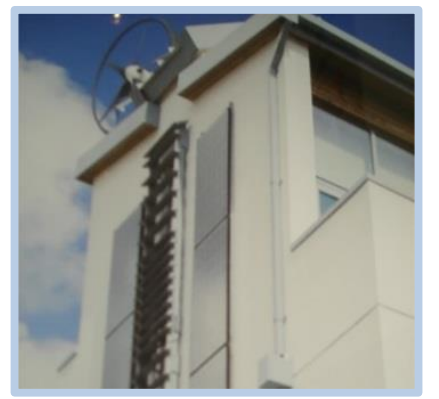

Figure 30: small scale wind mills placed on roof

Researcher_BRE innovation park(England)

Figure 31:smart energy integrated BRE innovation park(England)

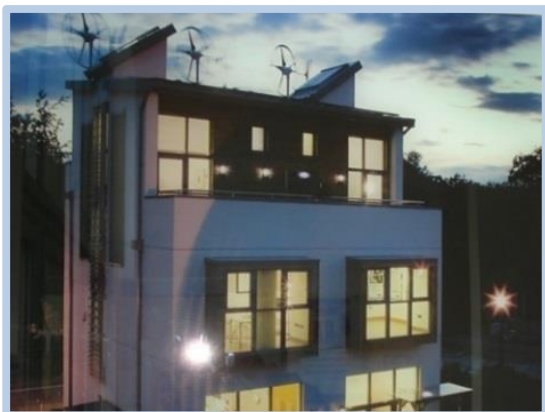

The application of BIWT systems to buildings can be done in two different ways. The first is to apply one or a few large-size wind turbines at two possible locations for large-size wind turbines:

- Inside a hole within a building that is specially designed;

- On the rooftop; and between two adjacent buildings; These types have already been applied to full-scale buildings such as the World Trade Center in Bahrain and Pearl River Tower in Guangzhou. Despite their high efficiency, however, it has been reported that they had several unsolved issues, such as noise and vibration problems caused by the large turbines and aesthetic dissatisfaction.

The second way to apply BIWT systems to buildings is to install many small-size wind turbines on the buildings instead of a few large-size wind turbines. This type of the BIWT system is considered as a convenient and economical method.

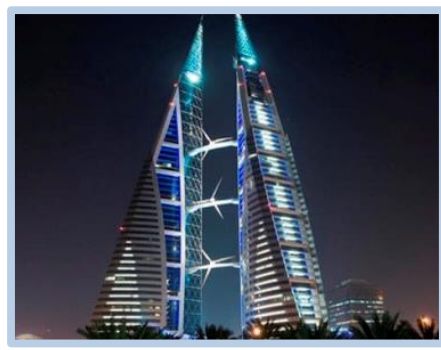

Figure 32: World Trade Center in Bahrain

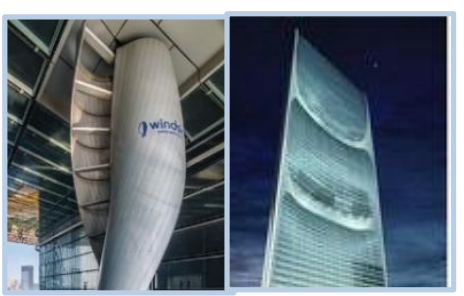

Figure 33:wind turbine in Pearl River Tower Wind turbine in homes applied in very limited places; on the rooftop, edges and limited places on facade. The ideal window to wall ratio for energy consumption is reported as $25 \%$ to $30 \%$ so there remains large installable area except for windows. Different from the conventional Building integrated wind turbine systems (Wen Tong Chong,2013).

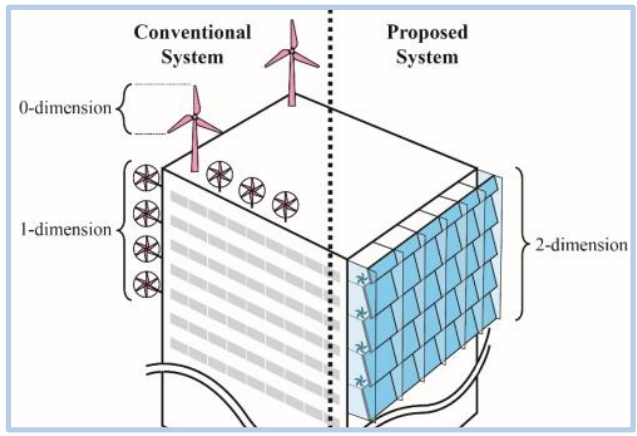

Figure 35 :wind turbine installation positions

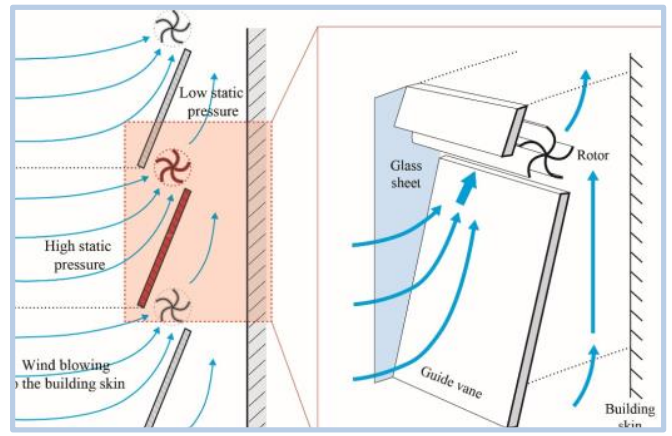

Figure 34 : Small scale wind turbine façade integration 


\subsection{Daylight:}

Daylight is a very important factor to be considered for energy saving, visual and thermal comfort. Daylight accompanied with glare especially from south and west facades in hot seasons can cause high heating loads and visual discomfort which will be inappropriate for residents and users, and this will make users to close window and use artificial light. Optimizing daylight and controlling the glare amount is the main way to reduces artificial light energy and will help in reduction of cooling loads at hot seasons. Designers should follow some passive design

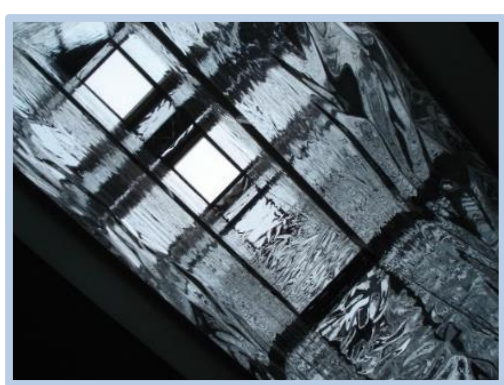

Figure 36: a mirror reflectors used from the roof, it reflects light to deliver indirect light to interior techniques to achieve comfort for occupants.

Windows at north facades are used for providing light without glare or sun exposures. bright color finishes used in the celling with reflectance value $70 \%$ helps in spreading light in the inner spaces. Also there is a mirror reflectors used from the roof accessed to the inner space, it reflects light more than one time in order to deliver indirect light to the inner spaces.

\subsection{Waste Management}

4.7.1. Waste Definition and Types:

Residential unit wastes mainly come from kitchen, bathrooms and plants, they are sorted into two forms solids and liquids wastes, the wastes management system dealing with solid wastes and water management systems dealing with liquid waste.

- Solid waste; for the kitchen solid wastes it comes in form of organic plastic, paper, metal, and glass. Organic waste is directly send biomass to underground tank from the kitchen through a chute, the organic wastes from kitchen and plants used in biomass for stoves, the biogas also used in generating energy as a reserve energy system for any electric deficit, while for the other kitchen wastes, they are sorted out at ground recycling pins into 4 categories; plastic, paper, metal, and glass.

- Liquid waste; separating toilet units at bathrooms to separate feces and urine intro different tanks to benefited from each element separately regarding to the feces its connected to drainage pipes to underground biomass tank directly for biomass production, urine comes from bathrooms units mixed with water with a specific mixing ratio 1:10 and separated via different separation methods as explained before and used in irrigation as it consists of natural fertilizers for roof and green wall area (Snigdhendubala Pradhan,et al,2019).

\subsection{Vegetation:}

sustainable research techniques should include vegetation and plantation process as its one of sustainable ecological aspects, the research finds that there is a three types of farming and vegetation; 
firstly, is the summer balcony that faced the north direction (prevailing wind direction) this type consist of fast growing organic food for the inhabitants such as carrot, beans lettuce, cabbage. Also plants used in air purification. Moreover, this balcony act as a wind catcher but designers has to integrate this balcony with the corridors and internal spaces to activate natural cross ventilation between north and south.

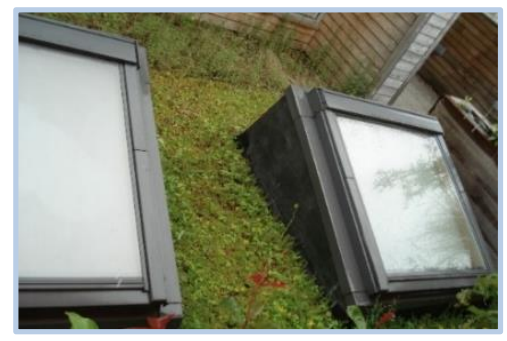

Figure 37: plantation used in roof secondly green wall is integrated in the unit design between the interior and exterior. It is appeared through the exterior facade as glazed exterior wall with plant pots on a grid creating a pleasant natural look from inside it is allow sunlight to pass through its glazing with shading from plants, the main purpose is to purify the inner space and at the same time releasing oxygen 24/7 such as Areca palm, Aleo vera.

Lastly, plantation used in roof as a small farm for edible plants for unit's inhabitant. roof farm helps in reducing heat gains by the roof to the space below and at the same time it creates a pleasant overlook to the building.

\subsection{Materials:}

\section{A. Smart Material}

Abound of definitions for smart materials have been released all over the world aiming to identify and signify what is the main aim of smart materials and how it affects our small world. Smart materials as "materials that "remember" configurations and can conform to them when given a specific stimulus' another definition of smart material by Encyclopaedia of Chemical "smart materials and structures are those objects that sense environmental events, process that sensory information, and then act on the environment" mainly smart material exhibits these characteristics:

- Immediacy - they respond in real-time.

- Transiency - they respond to more than one environmental state.

- Self-actuation - intelligence is internal to rather than external to the 'material'.

- Selectivity - their response is discrete and predictable.

- Directness - the response is local to the 'activating' event.

\subsection{Intelligent Structure}

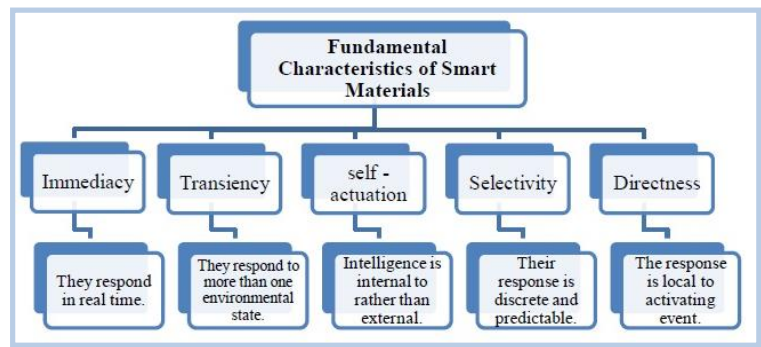

Figure 38: Fundamental characteristics of Smart Materials. Source: researcher based on (Addington, 2005)

The integration of complex application and equipment's in one building was too complicated to be made especially if not constructed in intelligent way. Smart structure becomes a real and a major icon to be taken in consideration in designing such an intelligent building. Smart building passes by two stages to implement an intelligent structure and this happen through smart construction and smart structure. Also it is 
from responsibility of the designer to design a precise, accurate and brilliant structure to adapt with users' needs and be able to change the function below it to different structure without any problems, and with less cost. Constructing a smart building has to be done in an intelligent execution by using smart material and smart equipment to increase efficiency and accuracy and at the same time save time and effort and this by its turn change project total cost. Smart structure should integrate all sustainable features and intelligent technologies and principles, designers should accomplish the best structural technique that accommodate with building design shape and the perfect orientation to the building design, and utilizing new Smart materials in design, so as to offer a complete integrated smart sustainable building.

\section{OPTIMIZATION METHOD AND EXPECTED OUTCOME:}

This Study is talking about; smart sustainable home with zero carbon emission, smart integrated systems, energy conservation, and energy production. Producing electricity via wind application in homes should be integrated smartly to achieve maximum benefit. As mentioned previously, a lot of simulation should be done to apply conventional passive techniques to any building, especially in homes, also integrating smart technologies is mandatory for achieving smart sustainable building. Based on key finding, its argued that consolidating smart sustainable concept is not an easy way to accomplish. an elaborated framework is educed from various architecture approaches starting from vernacular architecture and end with smart technological architecture aiming to visualize a real systematic structures criterion to follow. Smart sustainable ecological plan is commonly perceived among few architects. Alternatively, to generalize this sustainable concept According to what was stated in this study, the research aims to create criteria of evaluation about a new model which integrate smart architecture with environmental aspects under the umbrella of efficient sustainability. Considering the review of historical part and the objective of the study; the two research poles formulate SE evaluation criteria to follow, that specify building position in applying SE aspects. Analyzing the current cases that integrate between intelligent and ecological aspects clarify that this integration doesn't acquire occupants' needs, and there is a real gap in integrating and applying them in one building. Also creating such a smart ecological building must fulfill user needs as well as sustainable aspects.

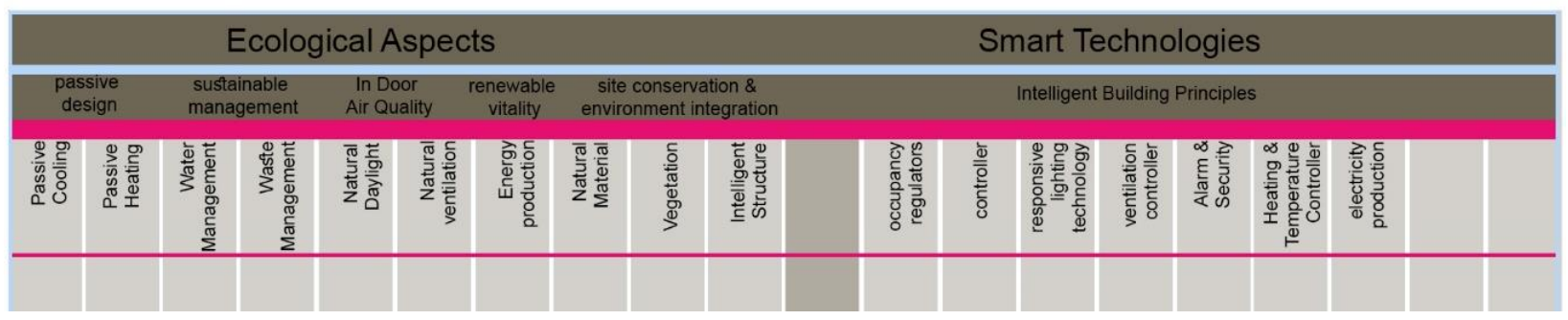

Figure 39:SE evaluation criteria to follow (researcher) 
Mohamed Momen Afifi/et al/Engineering Research Journal 163 (September 2019) A36 - A60

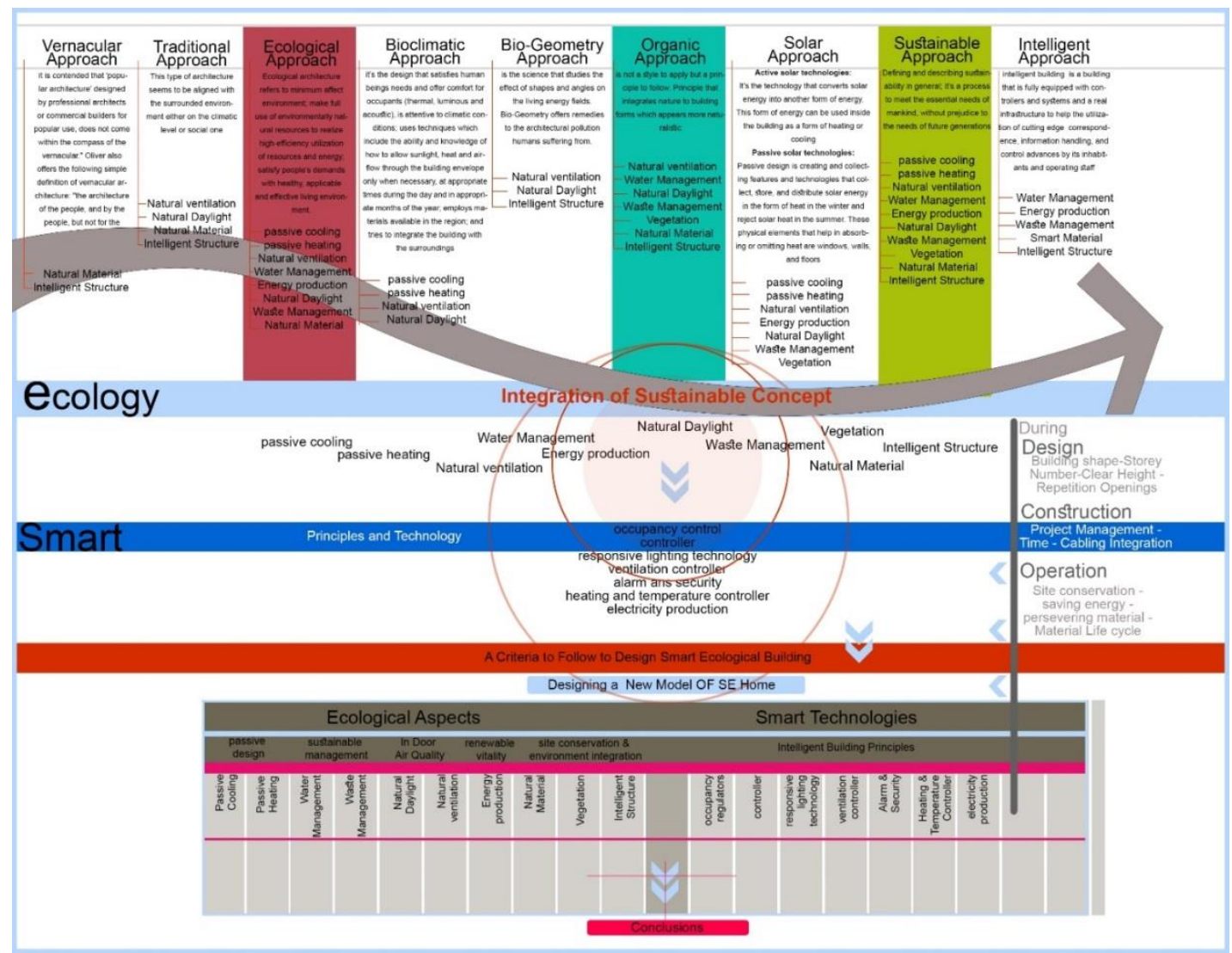

Figure 40:integration of sustainable concept- Smart ecological model. (researcher).

\section{Conclusion:}

This study showed the logical transformation of the architecture different approaches starting from vernacular architecture passing by ecological, bio-climatic, solar, green, and ends by intelligent attributes aiming to consolidate between nature and smartness.

Designing a smart sustainable home should be made in a highly matured way that use different techniques, principles and technologies, which are energy efficient, associated with environment protection and well-being of the building's occupants, construction workers, the general public, or future generations. Sustainable building involves the consideration of many issues, including land use, site impacts, indoor environment, energy and water use, lifecycle impacts of building materials, and solid waste. smart technologies and principles operate, manage, conserve energy, and offer human comfort inside the building entity.

Educing from this historical significance a specific point that affect the smart ecological home these points comes from the different types of architecture Approaches to achieve an elaborated criterion to investigate summarized in; Automation (BMS, BAS), environment protection, saving energy, indoor air quality, and responsiveness. Applying these aspects by using; Natural materials not toxic one, reducing construction waste which directly harms the environment. Also Saving energy are from the major points that must be taken in consideration during project life cycle by integrating smart systems in homes that not only save energy but also offers new technological renewable energies inside this homes. As well indoor air quality is form the aspects that directly affect occupants; ventilation, lighting, and 
sound isolation or/and conduction. Automation and responsiveness are intelligent home (IH) backbone, implementing those aspects is mandatory to create an intelligent sustainable home that accedes user's needs.

\section{Bibliography}

1. Badr Ahmed ,Magda, march 2010, " Intelligent Architecture, As an Approach for apply the Technological Development in the Environmental Control and Energy Efficiency in Buildings" ,p141.- (Arabic reference).

2. Environment, 2012, from an online dictionary (http://www.businessdictionary.com/definition/environment.html\#ixzz1nOhQutS5), Retrieved February 24, 2012

3. Yudelson Jerry, 2008," The green building revolution", Island Press, Washington, p1-p13.

4. Historical review for environmental aspects, 2012: http://www.architecture.com/SustainabilityHub/Designstrategies/Introduction/1-0-5Inbriefahistoryofsustainablearchitecture.aspx, Retrieved Feb. 28.

5. Oliver, Paul , 2003, Dwellings. London: Phaidon Press.p. 25

6. Lan , Ma , 2011, "Create a Harmonious Environment Together of Ecological Architecture Design Method", Elsevier Ltd, Science Direct Volume 10, Part B, Page1775.

7. Gallo, Cettina, May-August 1996, "Renewable Energy", IV Denver - Colorado, USA, Volume 8, Issues 1-4, P315.

8. Bio-geometrical architecture, 2012, http://www.biogeometry.com/english/applications.php,Retrieved Mar. 7, 2012.

9. Frank Lloyd Wright ,1954, "The Natural House "(New York: Bramhall House), p. 3

10. Organic architecture ,2012, http://www.organicarchitect.com/organic/\#axzz2UsENA6Bk Retrieved Mar.7, 2012.

11. Pearson, David, 2001, "The Breaking Wave: New Organic Architecture", p. 72.

12. Porteus, Colin, June 2008, "Power architecture, Engineering \& Technology",Ebsco host (Acadmic search, Vol. 3 Issue 9, 24 may - 6 p52.

13. Keith Robertson and Andreas Athienitis,"solar energy for building",Canada, p3. http://www.cmhc-schl.gc.ca/en/inpr/bude/himu/coedar/upload/OAA_En_aug10.pdf , Retrieved Feb. 12, 2012.

14. Doerr, Thomas ,2012, Passive Solar Simplified (1st ed.).

15. Mohamed, Nura S.; Darus, Zuhairuse M. D., Jan2011,"Planning Design for Affordable Housing and Green Architecture", European Journal of Social Science,Vol.18-4, p644.

16. Walter M. Kroner, 1989," The New Frontier Intelligent Architecture Through Intelligent Design", Butterworth \& Co (Publishers) Ltd,USA,NY, p.320.

17. Sayed abd el fatah, Eman, 2010,'Digital Globalization Role in Enhancement the Environmental Performance of Intelligent Building "unpublished thesis, Cairo Egypt, p37,-:Arabic reference".

18. Ed van Hinte, Marc Neelen, Jacques Vink, Piet Vollaard, 2003., "SMART ARCHITECTURE", 010 Publishers, Rotterdam, P9.

19. Ali Safdar,Kim Dohyeun.Visualization methodology of power consumption in homes. ICOSST 2013 - 2013 International Conference on Open Source Systems and Technologies, Proceedings;2013:55-59.

20. Ministry of electricity annual report, http://www.moee.gov.eg/english_new/EEHC_Rep/20162017en.pdf

21. 'Indoor Air Quality'”https://www.epa.gov/indoor-air-quality-iaq/introduction-indoor-air-quality ,retrieved at $1 / 4 / 2019$

22. Chris Reardon, et al.," your home-passive cooling" 4th ed., Dept. of Climate Change and Energy Efficiency,2013, p 135. 
23. Ayotunde Dawodua, Ali Cheshmehzangia, "Passive Cooling Energy Systems SWOT Analyses for Energy-Use Reductions at Three Spatial Levels", The 8th International Conference on Applied Energy, Elsevier Ltd,2017 p 3412.

24. R. Pacheco, J. Ordonez, G. Martinez, "Energy efficient design of building: A review", Elsevier Ltd, April 2012, p3562.

25. Florides GA, et al," Measures used to lower building energy consumption and their cost effectiveness", Applied Energy 2002, vol.73, p299-328.

26. Evangelos Bellos ,et.al,"An innovative Trombe wall as a passive heating system for a building in Athens-A comparison with the conventional Trombe wall and the insulated wall", Oct. 2016 Elsevier, Vol. 133, p.754.

27. Linden, P. F.,"The Fluid Mechanics of Natural Ventilation". Annual Review of Fluid Mechanics., 1999, Vol. 31, p 201-238

28. Walker, Andy. Natural Ventilation. National Institute of Building Science, httpwww.wbdg.orgresourcesnatural-ventilation, retrieved, May 2019.

29. Hossein Omrany, et al," Application of passive wall systems for improving the energy efficiency in buildings: A comprehensive review", Renewable and Sustainable Energy Reviews Vol 62, Elsevier Ltd. 2016, p 1259.

30. Prathapar, S., et al.," Overcoming constraints in treated greywater reuse in Oman".Desalination 186, 2005,p177-186.

31. Snigdhendubala Pradhan, Sami G. Al-Ghamdi, Hamish R. Mackey,"Greywater recycling in buildings using living walls and green roofs: A review of the applicability and challenges", Science of the Total Environment, Vol 652 Elsevier B.V.,2019,p330-334.

32. Ghisi, E.;deOliveira,S.M."Potential for potable water savings by combining the use of rainwater and greywater in houses in southern Brazil. 2007,Vol 42,p 1731-1742.

33. Santos, F. M., Rosa, J. L., Trento, L. C., Vedvotto, R., \& Lins, N.).” Indiscriminated use of water r (in Portuguese)"., Vol 5(47), 2017, p 29-37.

34. Larissa Carolina Corraide da Silvaa,et al, "Water sustainability potential in a university building", Sustainable Cities and Society, Vol 47, Elsevier Ltd.2019,p3.

35. Demanboro, A. C., Fabiano, B., Longo, R. M., \& Bettine, S. C., "Evaluation of water consumption on taps at a university". Vol 15,2015, p 135-143.

36. Lukas Huhn,et al, "GREYWATER TREATMENT IN SAND AND GRAVEL FILTERS", Manual for Design, Construction, Operation and Maintenance ,June 2015,p3.

37. “Subsurface_flow_constructed_wetland_for_greywater", retrieved April 2019, retrieved from(https://www.appropedia.org/Subsurface_flow_constructed_wetland_for_greywater)

38. F.L. Luo, H. Ye, "Laddered multilevel DC/AC inverters used in solar panel energy systems", IET Power Electron. Vol 6,2013, p 1769-1777.

39. Fadi AlFaris, ,et al,'Intelligent homes' technologies to optimize the energy performance for the net zero energy home", Energy and Buildings Vol 153 Elsevier B.V. 2017,p 267.

40. "SolarEnergy",retrievedMay2019, retrievedfrom(https://www.energy.gov/energysaver/articles/sola r-panel-design-ideas-your-home)

41. "Types of photovoltaic cells", retrievedFeb2019, retrievedfrom(http://www.nef.org.uk/knowledgehub/solar-energy/types-of-photovoltaic-pv-cells).

42. Hartman, J. "Researchers study potential of wind-powered buildings",Vol 71,2001, p 13.

43. Wen Tong Chong, Sin Chew Poh,Ahmad Fazlizan,'BUILDING INTEGRATED WIND ENERGY CONVERSION SYSTEMS FOR FUTURE CITIES", Nova Science Publishers, June 2013,p 2-7.

44. D. Michelle Addington, D. L. (2005). SMART MATERIALS AND NEW TECHNOLOGIES. UK: Architectural Press. 